\title{
Nominal ellipsis in Jordanian Arabic Advertisements
}

\author{
Bahjat Ahmad Rabee Alhalalmeh
}

\section{Abstract}

This research aims to explore the extent to which nominal ellipsis in Arabic is applied to its English counterpart in some selected cases; numeratives, epithets, possessives and quantifiers. The illustrative instances are taken from some Arabic advertisements in Jordanian newspapers. Discussions reveal that, among the selected cases above, nominal ellipsis in numeratives (cardinals \& ordinals) as well as epithets can function as head of an elliptical nominal group. Possessives cannot be upgraded to head function in the elliptical nominal group while quantifiers have a dual function; in fact some quantifiers can be upgraded to function as head but others cannot. In this respect, it could be concluded that nominal ellipsis in Arabic can be applied to its English counterpart in a large extent; most of the selected cases are applicable.

Key words: nominal ellipsis, advertisements. 
تحف هذة الدراسة الى إستكشاف مدى إمكانية تطبيق أنظمة حذف الإسم باللغة العربية

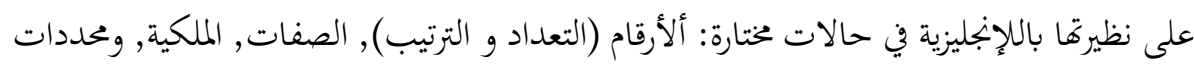

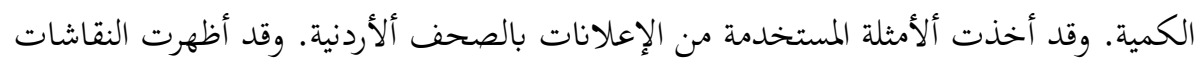

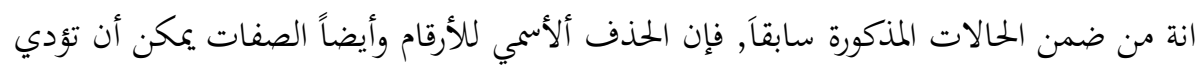

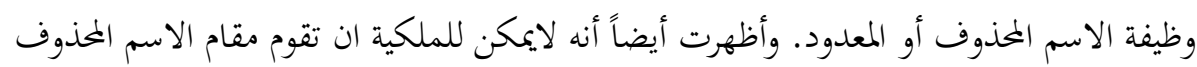

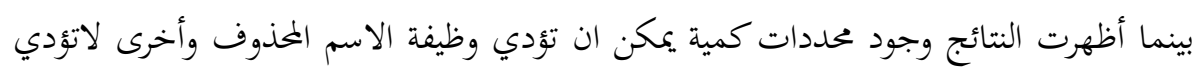
ذلك.لذا يمكن القول أن حذف الإسم بالعربية يمكن تطبيقة على نظيرته بألإنجليزية لدرجة كبيرة ضمن الحالات المختارة. الكلمات المفتاحية: حذف الإسم, ألإعلانات.

\section{Introduction:}

The present study aims at investigating nominal ellipsis in advertisements taken from Jordanian Arabic newspapers. Since advertisements are a reflection of real world type of communication in written documents, they could provide researchers with certain linguistic and stylistic representation of the writers' intentions while conveying their messages. The attractive power of advertisements sometimes advocates, persuades, asks and encourages consumers to act because they deeply touch minds. Advertisements are of great value for linguistic analyses for different linguistic perspectives. For instance, linguists are interested in the language of advertisements to show how such language genre works and 
what linguistic elements and means are used. This concept can explain the means of creating an advertising message and its success depends on the linguistic features employed. Sociolinguistics, for example, could focus on how advertisements influence society's behaviours, values or attitudes towards a particular product or service (Luna,D.\& Forquer Gupta, S, 2001). Psycholinguistics could explore their effect on human mind and their motivation (Dornyei, Z \& Ushioda, E, 2013). Other experts working in advertising and marketing may find it useful to have a particular language of advertisements in order to make them more attractive and effective. Advertising language often attempts to reproduce the elliptical nature found in spoken language in order to establish closeness with the reader.

Halliday and Hassan (1976, 1994) deal with ellipsis as a cohesive device binding the text together. They conceive the linguistic system as using grammar to regulate elements in the text that allow the speaker or writer to produce linguistic expressions characterized by the dependency and ties of the various elements on each other and which is called cohesion. They mention a number of devices which help in the achieving of this interdependence between elements. Ellipsis is one of the most prevailing devices in texts, which means the use of fewer expressed elements. Others locate ellipsis as performing a set of grammatical relations performing the role 
of a "cohesive device" in texts (Bayshak, 1991:100; Sweity, 1992: 109; Obeidat, 1994: 369).

\section{Research objective:}

The study aims to achieve the following objective:

- To identify the extent to which nominal ellipsis in Arabic is applied to its English counterparts in Jordanian advertisements.

\section{Research Question}

- How far nominal ellipsis in Arabic is applied to its English counterparts in Jordanian Advertisements?

\section{The data}

Many Arabic advertisements are used in this research which provide relevant instances for nominal ellipsis discussions in Arabic. These instances are used to show the extent to which nominal ellipsis in Arabic is applicable to its English counterparts. Illustrative examples are quoted from ads in $\mathrm{Al}$ rai, Al-Ghad and Al-waseet newspapers. 


\section{Ellipsis}

The common view of ellipsis is that it is something left unsaid but understood. The unsaid element/s could be supplied to the text to be understood. The missed elements could be gained from the general context since language functions as a text in actual situation (Halliday and Hassan, 1976: 142-143). Other linguists extend this argument:

Ellipsis is the physical deletion of elements of a sentence that the writer confidently believes the reader will insert on their own as they read. It is the reader, rather than the writer, who then supplies the missing elements to fill the gap. The writer can assume the gap will be filled in correctly only if the structure of the text provides the reader with the necessary clues about how to fill the missing material and when the topic and key terms of the passage remain consistent.

(Donnelly, 1994: 103-104):

De Beaugrande (1991:251) states that ellipsis "occurs when a clause or a part of a clause or a verbal or nominal group is presupposed at a subsequent place via positive omission, saying nothing where something is required to make up the sense". Moreover, ellipsis, for Donnelly (1994:105), is a device to achieve compactness in a text but it is important while using it not to "sacrifice clarity" and if the reader cannot recover the intended meaning, compactness is not worth the cost. Halliday 
and Hassan (1976:144) state that "ellipsis is normally anaphoric relation within the text; the presupposed item is present elsewhere in the previous text".

Thus, the main function of ellipsis in general terms is to create cohesion through certain selection of linguistic choices and systems within texts usually by anaphoric relations.

Halliday and Hassan (1976:144) and later on Halliday(1994:310) account to ellipsis as being typologically organized by three different structural units that are capable to undergo ellipsis: clausal ellipsis, verbal ellipsis and nominal ellipsis. They will be discussed below.

\section{Nominal Ellipsis in English}

Halliday and Hassan (1976:147) state that nominal ellipsis occurs within the nominal group. Moreover, Bloor and Bloor (2004:97) elaborate the argument that "nominal ellipsis permits the omission of head nouns in a nominal group". The structure of nominal groups is made of the head with optional modifiers; elements preceding the head are premodifiers and elements following the head are postmodifiers (Halliday and Hassan, 1976: 150). For example:

1. Those two fast electric trains with pantographs.

Premodifiers head postmodifiers 
Generally, modifiers can be one of the following:

a. Deictic (normally a determiner)

b. Numerative (a number or other quantifier)

c. Epithet (an adjective)

d. Classifier (a noun)

The head in the nominal group could be an animate object, person, quality, process, abstraction, institution, state or relation (ibid). When the head is omitted and another modifier takes its function, then this modifier will involve upgrading of a word functioning as Deictic, Epithet or Numerative from the status of Modifier to the status of Head. For example:

2. Four other Oysters followed them, and yet another four........

The 'four' in the coordinated clause, is a Numerative modifier, is upgraded to function as Head (ibid).

Halliday and Hassan (1976:153) state that the 'classifier' is very rarely left to function as 'Head'. The reason behind this is that the classifier is typically realized by a word that could also substitute that entity. The classifier can function as Head if it is not a noun as in the example:

3. Here are my silk scarves. 
Therefore, 'the most instances of ellipsis are those with Deictic or Nominative' (ibid: 155).

\section{Deictic}

In a nominal group, deictic can have two types: deictic proper and post-deictic. The former has two other distinctions that are most relevant to ellipsis. These distinctions are specific deictic and the non-specific. Halliday and Hassan (1976:155) highlight the necessity of deictic elements which "is a major source of cohesion in English texts. The deictic is the element in the nominal group that relates to the HERE AND NOW, linking the thing referred to, to its verbal and situational context".

\section{Specific Deictic}

Specific deictic is realized through possessives like nominal (my father's, Smith's, etc.) or pro-nominals (mine, his, her, etc.) and demonstratives (this, that, etc.) and 'the'. When a possessive occurs as a head in a nominal group, it is elliptical. It is also the case of third person pronominal (theirs, hers, etc.) where there is double cohesive devices: reference and ellipsis. Moreover, Halliday and Hassan (1976:155-157) state that all demonstratives occur elliptically and are more frequently anaphoric while 'the' does not operate elliptically since its function is to signal that the thing designated is fully defined, 
but by something other than 'the' itself, it normally requires another item with it, as in 'the two, the small'.

\section{Non-Specific Deictic}

These include 'each, every, either, neither, no, a, some, any, both and all'. All these occur as Head of an elliptical nominal group except 'every', 'no' and 'a' have to be represented by 'none and one' respectively. For example,

1. I hope no bones are broken? None to speak of. (ibid: 157).

The words 'all' and 'both' very frequently function elliptically. They may refer to a single nominal group; if so it will be plural, having the sense of two if presupposed by both and more than two if presupposed by all'( Halliday and Hassan,1976:155). 'either and neither' on the other hand, 'are like both in presupposing two sets; and each two more'(ibid).

\section{Post-Deictic}

The post deictics are adjectives. The most frequent ones include other, some, identical, usual, regular, certain, odd, famous, well-known, typical and obvious. These could be followed by a numerative, e.g.,

1. The identical three questions. (deictic)

2. Three identical questions. (epithet) 
The post deictic other may combine with either specific deictic (the other, that other) or with non-specific deictic (any other). For example,

3. I have used up these three yellow folders you gave me.

Can I use the other?

The word 'other' does not mean 'the other three', but the last remaining member (ibid: 158).

\section{Numeratives}

Only numeratives can function as the head in ellipsis. The numerative element in the nominal group is expressed by numerals or other three sub-categories: ordinals, cardinals and indefinite quantifiers (Halliday and Hassan, 1976: 161). Ordinals include first, second, last, etc. They are usually used with the as in the first, the second or with possessives as in 'Have another chocolate. No, thanks that was my third. Cardinal numerals are also frequent in nominal group ellipsis and could be preceded by any appropriate deictic, e.g., the four, those four and any four, etc.

The indefinite quantifiers also belong to numeratives, such as many, more, most, few a little, lots, a bit and hundreds. Much, many, more and several are used frequently in ellipsis 
since they are indefinite; they are not usually accompanied by deictic. For example,

1. 'I'll get one. The knight said thoughtfully to himself. One or two-several'(ibid: 161-163).

\section{Epithet}

The function of epithets is usually realized by an adjective. Superlative adjectives as well as color adjectives are more frequent. Halliday and Mattiesen, 2014: 376) state that the function of 'the epithet indicates some quality of the sub-set, e.g. old, long, blue, fast'. The superlative adjectives precede other epithets and usually accompanied by the or a possessive deictic as respectively exemplified,

1. Apples are the cheapest in autumn. ' the cheapest' is an elliptical nominal group presupposed by some items such as fruit.

2. It is my loveliest.

Furthermore, a nominal group with comparatives functions as Headin elliptical nominal group. For example,

3. I'll buy you some prettier.

One use of true comparative which is confusing as it is preceded by the and looks like superlative as in: 
4. The smallest the dog, the louder the bark.

In this example, the is not deictic but a sub-modifier with a sense of 'by how much' or 'by that much' (Halliday and Hassan, 1976: 164-165).

From the above mentioned English nominal group types, this study concerns comparing numeratives, epithets, possessives and quantifiers to its Arabic counterpart.

\section{Nominal Ellipsis in Arabic}

This section involves selective points that shed light on nominal ellipsis in Arabic ads. On the first hand, description of the nominal ellipsis in both Arabic and English will be provided. On the other, certain Arabic and English ads will be compared to find out which language exhibits redundant vs. elliptical elements.

Ellipsis is an interdisciplinary linguistic field that could include the interfaces of syntax, phonology, semantics and pragmatics. Lobek (1995:20) defines ellipsis as the "omission of a syntactic constituent under identity with an antecedent in the preceding discourse." Thus, ellipsis is considered a cohesive device whenever the elided elements are only recoverable from through making presuppositions to the antecedent (anaphoric) or following (cataphoric) to form endophoric relation. However, systemic functional linguistics, as 
mentioned earlier, realizes language as a communicative means to convey messages through the interlocutors or even the society. It could be concluded that recoverability could also be realized through contexts or even through ones' knowledge about the grammar of a language.

This section is devoted to discuss mainly nominal ellipsis that occurs within nominal groups. It involves the upgrading of a word functioning as deictic, numerative, epithet or classifier from the status of modifier to the status of head (Halliday and Hassan, 1976:148).

Ellipsis is a linguistic phenomenon that presents in human languages. In Arabic, it has stable features that tend to be brief and concise. The style of conciseness is recognized by ellipsis and shortening. Az Zarkashi (2001, vol,3: 115) states that " ellipsis is dropping a part of the speech or all of it for a cause, originally with all different kinds of ellipsis". Moreover, he mentions that in ellipting a word or more from a sentence, a speaker or writer should leave some evidence that facilitates its interpretation. This evidence could be verbal or circumstantial (ibid: 127). In the case of verbal evidence, the listener or the reader has to think of the syntax and the sentence pattern to infer the deleted elements. When the context of the situation, the elements surrounding the absent elements and the knowledge of the reader or the listener help in inferring the absent elements, then a circumstantial evidence is met. 
This section is devoted to discuss nominal ellipsis in Arabic, in particular, with reference to Halliday (1967) classifications; deictic, numeratives, epithets and classifiers. Nominal ellipsis occurs only when the head noun of a noun phrase is left unsaid and it is associated with the sense of incompleteness. Since nominal ellipsis is to keep a relationship between the different parts of the discourse, the head noun of an elliptical nominal group is to be recovered from the context of the discourse. The importance of nominal ellipsis is making the discourse more cohesive by forming relations or ties that connect the parts of the discourse.

In nominal ellipsis, the head noun of a noun phrase is omitted and a noun modifying it is upgraded to function as the head of that noun phrase. The modifiers include those elements preceding head noun (pre-modifiers) and those following head noun (post-modifiers). Some of the Arabic linguistic elements (modifiers) that function as head in an elliptical nominal group will be discussed in this section. The Arabic modifiers will be explored are numeratives, adjectives, possessives and quantifiers. These modifiers are given in the table below: 
Table (8) The Arabic modifiers functioning as head of the elliptical nominal elements

\begin{tabular}{|c|l|l|l|l|}
\hline \multicolumn{2}{|l|}{ Modifiers } & Type & Markers & Gloss \\
\hline \multirow{2}{*}{ 1. } & \multirow{2}{*}{ Numeratives } & Cardinal & $\begin{array}{l}\text { Wahid, Ithnan, } \\
\text { Thalathah...etc }\end{array}$ & $\begin{array}{l}\text { One, two, } \\
\text { Three }\end{array}$ \\
\cline { 3 - 5 } & Ordinal & $\begin{array}{l}\text { Al-awal, Al-thani, Al- } \\
\text { thalith }\end{array}$ & $\begin{array}{l}\text { First, } \\
\text { second, } \\
\text { Third }\end{array}$ \\
\hline 2. & Adjectives & Attributives & $\begin{array}{l}\text { Qadeem, Jadeed, } \\
\text { Jayid }\end{array}$ & $\begin{array}{l}\text { Old, new, } \\
\text { good }\end{array}$ \\
\hline \multirow{2}{*}{ 3. } & \multirow{2}{*}{ Possessives } & Noun & $\begin{array}{l}\text { Noun+noun } \\
\text { Sayyaratu Ahmed }\end{array}$ & $\begin{array}{l}\text { Of } \\
\text { someone }\end{array}$ \\
\cline { 3 - 5 } 4. & Pronoun & Sayyaratuhu & $\begin{array}{l}\text { Of } \\
\text { someone }\end{array}$ \\
\cline { 2 - 5 } & Quantifiers & & Kul, Baidh, Qalil & $\begin{array}{l}\text { All, some, } \\
\text { a little }\end{array}$ \\
\hline
\end{tabular}

\section{Numeratives}

In Arabic nominal ellipsis, a numeratives is one of the linguistic elements that can be upgraded to function as a head of an elliptical nominal group. If there is an elliptical nominal group, there will be a noun modifying elements than can function as head of that nominal group. It is possible for numeratives to function as head of the nominal that is elliptical because of having a presupposed element in the preceding part of discourse.

\section{The Cardinals}


The Arabic numeratives to be explored in this section are: the cardinals like 'wahid', 'Ithnan', 'one', 'two'...etc. These cardinals can be upgraded to become the head of an elliptical nominal group as exemplified below:

$$
\text { 1. A: Aل اشتريت تقويم هذه السنه؟ }
$$

Have you bought the calendar of this year?

B: نعم اشتريت واحدا

Yes, I have bought one.

In this example, the B's answer has an elliptical nominal group. The cardinal "wahid'واحدا as head of the elliptical nominal group. The non-elliptical counterpart of this sentence could be the following:

"تعم اشتريت تقويما واحدا ' ' Thus, the noun “' calendar' is deleted and the cardinal is upgraded to have its function; head of the nominal group. These cardinals are working as modifiers and are accompanied with a head noun. When the nominal group is elliptical, the head noun is omitted but understood, cardinals will remain heads of that elliptical group.

The cardinal 'wahid, one' could also be used to function as head in nominal substitution. However, there is a difference between the elliptical 'Wahid, واحد, one' and the substitute 'wahid,واحد, gone'. In the nominal substitution, 'wahid, one' 
which is used as a substitute item will be preceded by a modifying element to have this interpretation:

'نعم اشتريت تقويما' On the other hand, in nominal ellipsis the cardinal wahid واحد, one' will stand alone as the head of a nominal group where the head noun is omitted; substituted by zero.

Another example is the following:

- يوجد بعض الاقلام على الطاوله, خذ اثنان

There are some pens on the table, take two.

In the above example, the nominal group of the second sentence is made up of the cardinal “ اثنان, ithnan, 'two' only. The cardinal 'اثنان, two' functions as a head of the nominal group in which the head noun is omitted. Thus, the complete non-elliptical form of the nominal group would be 'قلمان اثنان' , 'two pens' because it has anaphoric relation between the cardinal 'اثنان, two' and the presupposed noun 'قلم, pen'.

\section{The Ordinals}

The ordinals in Arabic are also used to have the same function; head of a nominal ellipsis in nominal groups. For example,

1-A: اي غرفة اختار عمر؟ 
Which did Omar choose?
B: اختار عمر الثالثة

\section{Omar chose the third.}

The ordinal 'الثالثه, the third' is used as head of the of the elliptical nominal group in B's utterance, where 'الغرفه , room' is omitted. The full non-elliptical form of the nominal group in the second utterance would be 'الغرفة الثالثه', the third room'. As nominal ellipsis occurs in this nominal group, a noun is omitted and the ordinal is upgraded to function as its head. After the head noun of the nominal group is understood and the ordinal becomes the head of that group, this nominal group is then becomes elliptical.

Within the discourse of ads, elliptical nominal group is found frequent. Ordinals are used where they are upgraded to function as head instead of the noun in that nominal phrase. Three different occurrences of the ordinal have been found in different ads but with the same reference. The first occurrence is when there is no ellipsis if the head noun is mentioned once and if there is no preceding referent. The second is when there is ellipsis if the head nominal noun has anaphoric relation. The third is when there is ellipsis without having anaphoric relation. These occurrences are respectively exemplified:

"3دونم موقع مميز على الدوار السادس مباشرة"-1" 
"3 acres are in special location on the Sixth Circle." (Al-rai, March 11, 2018)

-"شقق فاخره للبيع في ارقى مناطق جبل عمان ( الدوار الخامس-الرابع) مساحات تبدا - 2

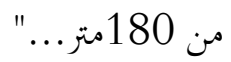

"Luxury apartments for sale in the most elegant areas of Jabal Amman (Fifth Circle - the Fourth) areas starting from 180 meters ...(Al-rai, March 12, 2018)

"ارض مساحه من 500متر لغاية 6000متر او فيلا قديمه للهدم في دير غبار, ام اذينه, -3 الرابيه, عبدون, الرونق بين الخامس والرابع, خلدا....

"Land area of 500 meters up to 6000 meters or an old villa for demolition in Deir Ghbar, Um Athina, Abdoun, Rounaq between the fifth and the fourth, Khalda ..." (Al-rai, March 14, 2018)

In the first instance of this group, the ordinal functions as a modifier of the noun. Thus, the ordinal 'السادس, the sixth' is a pre-modifier of the head noun ' الدوار, Circle', where no ellipsis occurs. However, in the second example, the ordinal 'الرابع, the fourth' is upgraded to function as head of the elliptical nominal group. The full non-elliptical form would be 'الدوار الرابع, the fourth Circle'. The presupposition of 'الدوار الخامس, the fourth Circle' explains the process of recoverability and the insertion of the omitted elements and its interpretation. 
The third example manifests an ambiguous situation where the recoverability is mainly culture bound source of recoverability interpretation. Within the same ad there is no presupposition of the head nominal that is omitted. The two ordinals 'الخامس والرابع, the fifth and the fourth' occurs in the same sentence where there is no antecedent that explains or helps the reader to have the right interpretation. The ordinals " الخامس والرابع, the fifth and the fourth' are upgraded to function as head of the elliptical nominal group. As it is the case of ordinals in English, ordinals in Arabic cannot occur without an explicit anaphoric relation. However, in the context of the Jordanian community, these cases are easily interpretable. Advertisers' knowledge of the readers' social and cultural background encourages them to overstate ellipsis. The shared knowledge between the advertisers and consumers or readers removes the ambiguity of recoverability.

\section{The epithets}

Epithets are belonging to the group of the adjectives category. These epithets are used as head of an elliptical nominal group in Arabic. In Arabic, adjectives are structurally formed by following nouns; noun+ adjective. In nominal groups, adjectives are accompanied with a head noun. When nominal ellipsis occurs, the head noun of the nominal group will be omitted and the adjective in that nominal group is 
upgraded and becomes head of the elliptical nominal group. The Arabic adjectives are like 'جيد, good', جديد, new', اسود, black'. For example:

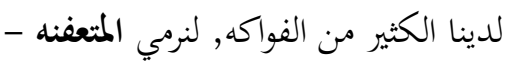

We have a lot of fruits, let's throw the rotten.

In the example above, there is an adjective 'متعفه, rotten' functioning as head of the elliptical nominal group. The adjective 'متعفنه, rotten' refers back to the noun 'الفواكه, fruits' in the preceding utterance. Thus, the non-elliptical nominal form of the nominal group would be 'الفواكه المتعفنه, the rotten fruits'. It is realized that the omitted head noun must be the noun 'الفواكه', fruits' since it has already been mentioned in the preceding utterance. This illustrates the fact that nominal ellipsis occurs only when there is a presupposition.

هل شاهدت الاقلام ؟ أحضر ألأسود. - - - مل

Have you seen the pens? Bring the black.

In this example, the non-elliptical form of the nominal group is 'القلم ألأسود, the black pen'. The color adjective 'الاسود, the black' is upgraded to function as head of the elliptical nominal group. Taking in consideration the differences that result from plural Vs. singular head nouns, the elliptical element is recoverable from the antecedent question even 
though they are not orthographically identical; the elliptical and the non-elliptical.

In the context of advertisements, similar cases when adjectives function as head are found frequent. For example,

للبيع قطعة ارض ترخيص ابراج 3 دونم موقع ميز على الدوار السادس مباشرة. مدفوعة العوائد لبناء 15الف متر بارتفاع 18طابق.

For sale a plot of land licensed for towers 3 dunums located on the Sixth Circle directly. Paid revenues to build 15,000 meters high, 18 floors high

$$
\text { (Al-rai, March 11, 2018) }
$$

In this example, there is nominal ellipsis. The adjective 'مدفوعه, paid' functions as head of the nominal group. The full non-elliptical form would be 'القطعه مدفوعة, the apartments are paid '. It is realized that the omitted head noun 'القطعه' that has already been mentioned in the preceding discourse of the advertisement and the adjective'مدفوعة' is upgraded to have head function of the elliptical nominal group. In this example, nominal ellipsis occurs when there is a presupposition.

$$
\text { شقق فاخرة للبيع في ارقى مناطق جبل عمان, الدوار الخامس -الرابع- مواصفات عاليه, بناء حديث, مواقف مؤمنه والتسليم فوري. }
$$

$$
\text { (Al-rai, March 12, 2018) }
$$


Luxury apartments for sale in the highest areas of Jabal Amman ( Fifth Circle - the fourth).

High specifications, modern building, available parking and immediate Delivery.

Another example is found to be highly elliptical one. Nominal ellipsis occurs repeatedly. The adjectives 'عاليه, high', ' فوري ' حديث, modern' and all function as head after the noun;

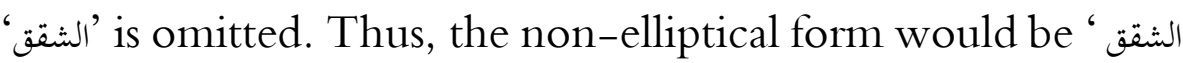
عالية, high apartments', 'الشقق حديث, modern apartments' and 'الشقق فوري' immediate apartment'. These adjectives are upgraded to function as head in the elliptical nominal group. The head noun 'الشقق' is mentioned in the preceding discourse . It is recovered from the previous context. However, in the same ad, another nominal ellipsis occurs but without presupposition from the preceding elements. The adjective 'مؤمنه, available' is upgraded to function as head of the elliptical nominal group. The non-elliptical nominal form would be 'السيارات مؤمنه, available cars'. Although the head noun 'السيارة, car' is not mentioned in the preceding discourse but inferred contextually.

ل0799088830: لكادين فتط

- For the serious only: 0799088830

(Al-rai, March 11, 2018) 
فرصة استثماريه لشركات الاسكان-

ارض بمنطقة الجبيهه 750م

- Investment opportunity for housing companies

Land in Jubaiha area $750 \mathrm{~m}$

\section{(Al-waseet, August 11, 2018)}

This example is taken from a land advertisement. It also exhibits an elliptical nominal ellipsis where the adjective 'استثماريه, investment' is upgraded to function as head in the elliptical nominal group. The full non-elliptical form would be 'ارض استثماريه, land investment' where 'ارض' is omitted but recovered from the following discourse.

للمهنمين 078068660-

-for interested 078068660

(Al-rai, February 6, 2018)

This example shows a different case of elliptical nominal group in which the elliptical head noun is recovered contextually. The adjective 'مهتمين, interested' is upgraded to function as head in the elliptical nominal group.

The full non- elliptical form would be 'للأشخاص المهتمين,' for interested people'. The head noun is neither mentioned in the 
preceding nor in the following discourse of the ad but easily retrieved contextually.

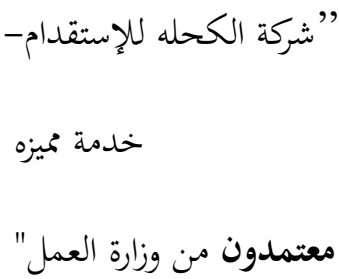

-Al Kahlah Recruitment Company

Excellent service

Accredited by the Ministry of Labor.

(Al-Ghad 13, 2018)

Another case of elliptical nominal group occurs in this example. The adjective 'معتمدون, accredited' is upgraded to function as head of the elliptical nominal group. The nonelliptical counterpart would be 'مالكو شركة الكحله معتمدون', the owners of Al Kahla recruitment company is accredited'. The head noun is recovered from the preceding discourse.

\section{Possessives}

Possessives are not used to function as head in the elliptical nominal group in Arabic. The possessive forms in Arabic could be a noun or a pronoun. In the case of nouns, possessives 
precede nouns without suffixations e.g. 'كتاب الولد, the boy's book', 'كتاب الاولاد, the boys' book' and ' كتاب البنت, the girl's book'. In the case of pronouns, it is suffixed with an appropriate pronoun marker e.g. 'كتابه, his book', 'كتابهم, their book,' and 'كتاهَ, her book' respectively. For example:

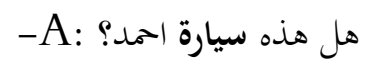

Is this Ahmed's car?

B: - نعم هذه سيارته.

Yes, it is his.

In this example, one can realizes that there is no ellipsis in the nominal group; Ahmad is not undergo ellipsis, but it is substituted by the referent pronoun 's'which refers to Ahmad in the word 'سيارته, his car' in B's utterance. Thus, it is ungrammatical in Arabic to say ' نعم هذه سيارته احمد' yes, it is his car Ahmad'. Thus, it could be concluded that Arabic and English differ in the case of ellipsis regarding the possessives. This could be attributed to the differences related to each language sentence structures; while English allows ellipsis of the possessed, Arabic does not.

\section{Quantifiers}

In Arabic, the quantifiers like 'كل, all', 'قليل', 'a little' and 'بعض, some' can function as head in the elliptical nominal 
group. These quantifiers can occur within a nominal group. They can occur with an omitted or non-omitted head noun. Quantifiers are contributing to function as head of a nominal group.

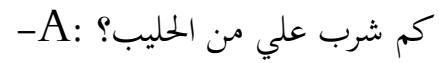

How much milk did Ali drink?

B: شرب الكثير

In this example, the head noun of the elliptical nominal group in which 'الكثير', 'much' is omitted. Since quantifiers occur with a head noun of a nominal group, they cannot stand alone. It has been realized that the head noun is omitted and the quantifier remains to function as the head of its elliptical nominal group. The quantifier 'الكثير, much' is the head of its nominal group. As nominal ellipsis has presupposition, the quantifier presupposes the person or thing from the preceding part of the discourse.

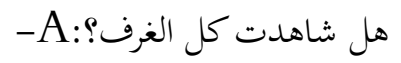

Have you seen all the rooms?

B: نعم شاهدت الكل.

Yes, I have seen all. 
In the example above, the head noun is 'الغرف', rooms' is omitted in B's utterance and the quantifier 'الكل', all' seems to function as head of that elliptical nominal group. However, the definite article 'لl, the' is attached to the quantifier to become 'الكل ", the all'. The B answer would be unacceptable if he says "

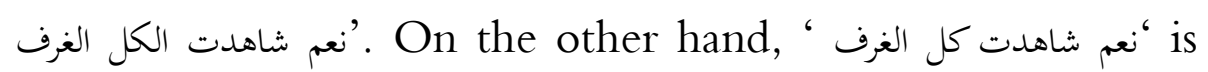
acceptable. Another evidence that supports considering the definite Arabic article that attaches quantifiers as referent comes from pronouns. For example:

- نعم شاهدت الكم is ungrammatical. نعم شاهدت الكل الغرف is

- نعم شاهدت كلهم is also ungrammatical. نعم شاهدت الكلهم

It could be concluded that the definite article in 'الكل', the all' functions as referent to head noun 'الغرف, the rooms', or the pronoun 'ه, them'. Thus, these examples do not undergo ellipsis.

As it the case with all other quantifiers in Arabic, if the definite article ' $\mathrm{J}$, the' is considered a referent pronoun, the sentence cannot undergo nominal ellipsis. If the definite article ' $J$, the' is not considered as a pronoun, the sentence explicitly undergoes elliptical nominal ellipsis.

\section{Summary \& Conclusion}


The research concentrated on certain nominal group issues in Arabic. It explored the numeratives, epithets, possessives and quantifiers. The goal was to examine the extent to which these types are applied to its English counterparts. Discussions reveal that among the selected cases above nominal ellipsis in numeratives (cardinals \& ordinals) as well as epithets can function as head of an elliptical nominal group. Possessives cannot be upgraded to head function in the elliptical nominal group while quantifiers have a dual function; in fact some quantifiers can be upgraded to function as head but others cannot.

\section{References}

Bayshak, M.(1991). A Study of Cohesion in Arabic based on Al-Jurjani's theory of Annazm (Doctoral dissertation, School of Oriental and African Studies (University of London)).

Bloor, T., \& Bloor, M.( 2004). The Functional Analyses of English: A Hallidayan Approach. London: Arnold.

De Beaugrand, R \& Dressller,U.(1981). Introduction to Text Linguistics. London: Longman.

Donnelly, C.( 1994). Linguistics for Writers. Albany, NY: State University of New York Press.

Dornyei, Z.\& Ushioda, E. (2013). Teaching and Researching: Motivation. Routledge. 
Eggins, S. (1994). An Introduction to Systemic Functional Linguistics. London and New York : Printer.

Halliday, M.(1967). Notes on Transitivity and Theme in English, parts 1-3. In Journal of Linguistics 3 (1), 37-81, 3 (2), 199-244 \& 4 (2), 179-215.

Halliday, M. A. K.\& Hasan.R . (1976). Cohesion in English. London: Longman.

Halliday, M. \& Mattiessen,C. (1994). An Introduction to Functional Grammar. $2^{\text {nd }}$ edition. London : Arnold.

Halliyday, M., \& Mattiessen, C.(2014). An Introduction to Functional Grammar. London: Routledge.

Lobeck, A. (1995): Ellipsis: Functional heads, licensing, and identification. New York: Oxford University Press.

Luna, D., \& Forquer Gupta, S. (2001). An Integrative Framework for Cross-cultural consumer behavior. International Marketing Review, 18(1), 45-69.

Obeidat, N.(1994). The Presentation of Thematic Structure in the Translation of English and Arabic Political Discourse (Doctoral dissertation, University of Durham). 
Sweity, A.(1992). Al-Jurjani's Theory of Nazm (Discourse Arrangement ):A Linguistic Perspective. Ann Arbor, Michigan: University Microfilms International. 